\title{
Seroprevalence and B1 gene Phylogeny of Toxoplasma gondii of Dogs and Cats in Republic of Korea
}

\author{
Yeojin Park', Jinhyeong Noh', Hyun-Ji Seo'1, Keun-Ho Kim¹, Subin Min¹, Mi-Sun Yoo', Bo-Ram Yun', Jong-Ho Kim², \\ Eun-Jin Choi ${ }^{2}$, Doo-Sung Cheon ${ }^{3}$, Sung-Jong Hong ${ }^{4}$, Soon-Seek Yoon', Yun Sang Cho',** \\ ${ }^{1}$ Parasitic and Honeybee Disease Laboratory, Bacterial and Parasitic Disease Division, Department of Animal \& Plant Health Research, Animal and \\ Plant Quarantine Agency, Gimcheon 39660, Korea; ${ }^{2}$ Animal Pathodiagnostic Laboratory, Animal Disease Diagnostic Division, Department of Disease \\ Control \& Quarantine, Animal and Plant Quarantine Agency, Gimcheon 39660, Korea; ${ }^{3}$ Postbio Inc., Guri 11906, Korea; ${ }^{4}$ Department of Medical \\ Environmental Biology, Chung-Ang University College of Medicine, Seoul 06974, Korea
}

\begin{abstract}
The outbreak of human toxoplasmosis can be attributed to ingestion of food contaminated with Toxoplasma gondii. Toxoplasmosis recently increased in domestic and stray dogs and cats. It prompted studies on the zoonotic infectious diseases transmitted via these animals. Sero- and antigen prevalences of $T$. gondii in dogs and cats were surveyed using ELISA and PCR, and B1 gene phylogeny was analyzed in this study. Toxoplasmosis antibodies were measured on sera of 403 stray cats, 947 stray dogs, 909 domestic cats, and 2,412 domestic dogs collected at nationwide regions, Korea from 2017 to 2019. In addition, whole blood, feces, and tissue samples were also collected from stray cats (1,392), stray dogs (686), domestic cats (3,040), and domestic dogs (1,974), and T. gondii-specific B1 gene PCR was performed. Antibody prevalence of stray cats, stray dogs, domestic cats, and domestic dogs were $14.1 \%, 5.6 \%, 2.3 \%$, and $0.04 \%$, respectively. Antigen prevalence of these animals was $0.5 \%, 0.2 \%, 0.1 \%$, and $0.4 \%$, respectively. Stray cats revealed the highest infection rate of toxoplasmosis, followed by stray dogs, domestic cats, and domestic dogs. B1 gene positives were 5 of stray cats, and identified to high/moderate pathogenic Type I/III group. These findings enforce that preventive hygienic measure should be strengthened at One Health level in dogs and cats, domestic and stray, to minimize human toxoplasmosis infections.
\end{abstract}

Key words: Toxoplasma gondii, seroprevalence, antigen, phylogeny, PCR, Korea

\section{INTRODUCTION}

As of 2018, the number of domestic dogs newly registered in Korea is 146,617 , which is an increase of $39.8 \%$ compared to the previous year [1]. The total number of dogs registered by 2018 is $13,340,477$ in Korea [1]. In addition, there were 12,077 rescued or protected abandoned animals in 2018. Among them, dogs accounted for $75.8 \%$ and cats for $23.2 \%$. In recent years, the number of companion and stray dogs and cats is on the rise, so it is time to be more alert to the spread of the zoonotic infectious diseases in Korea.

Human toxoplasmosis is an infection caused by the parasite Toxoplasma gondii and can occur through ingestion of contaminated meat or exposure to feces from infected animals. Al-

\footnotetext{
- Received 20 March 2020, revised 11 June 2020, accepted 11 June 2020.

*Corresponding author (choys@korea.kr)

(c) 2020, Korean Society for Parasitology and Tropical Medicine

This is an Open Access article distributed under the terms of the Creative Commons

Attribution Non-Commercial License (https://creativecommons.org/licenses/by-nc/4.0) which permits unrestricted non-commercial use, distribution, and reproduction in any

medium, provided the original work is properly cited.
}

though toxoplasmosis is mostly asymptomatic in humans, it is fatal in immunocompromised people and pregnant women, who may experience birth defects or miscarriage due to infection $[2,3]$. Toxoplasmosis can occur in all warm-blooded animals, and the feces of the infected cats are a prominent source of transmission [4,5]. Moreover, dogs have recently been identified as positive carrier of $T$. gondii via antigen and antibody tests, and mechanical transmission through dogs has therefore emerged as a growing concern [6-9].

The seroprevalence of $T$. gondii in cats varies greatly among different countries $[4,8,10-18]$. Even in the same country, the rate of positivity varies considerably depending on where the sample was taken, which test method was used, etc [10,19-21]. In Korea, many researchers have investigated the status of feline toxoplasmosis infection [10,19-24]. However, 1 study regarding the status of infection with toxoplasmosis in dogs has been conducted during 2006-2007 [22]. In this study, we collected the samples from domestic and stray dogs and cats in Korea during 2017-2019, and investigated the infection status of toxoplasmosis of dogs and cats by P30 antibody ELISA and 
B1 gene antigen PCR.

\section{MATERIALS AND METHODS}

\section{Sample collection}

A total of 7,092 blood, fecal and tissue samples and 4,671 serum samples were collected for antigen detection and serological tests, respectively, from 2017 to 2019 in 9 regions of Korea (Seoul-Gyeonggi-Incheon, Gangwon, Chungbuk, Daejeon-Sejong-Chungnam, Jeonbuk, Gwangju-Jeonnam, DeaguGyeongbuk, Busan-Ulsan-Gyeongnam, and Jeju). The protocol for animal experiments was approved by the Institutional Animal Care and Use Committee (IACUC) of the Animal and Plant Quarantine Agency (APQA) (Approval Number 2018400 and 2019-456). Canine blood samples were collected from domestic dogs $(n=1,974)$, as well as stray dogs $(n=686)$ from the abandoned animal shelter in 9 regions of Korea. Whole blood samples from dogs were collected using syringes with 26-gauge needles and transferred to BD Vacutainer ${ }^{\circledR}$ Heparin blood collection tubes (Becton, Dickinson and Company, Franklin Lakes, New Jersey, USA). Blood and fecal samples were collected from domestic and stray cats in the veterinary clinics. Whole blood samples from cats were transferred to BD Microtainer ${ }^{\circledR}$ Tubes with $\mathrm{K}_{2}$ EDTA (Becton, Dickinson and Company). Feces from cats were obtained manually at animal clinics and shelters of stray cats. From domestic cats, we collected 1,014 of blood samples, and from stray cats, 406 of blood samples and 514 of fecal samples. Cat tissue samples $(n=472)$ were obtained from cats, which were sent to the Department of Disease Diagnosis - Animal and Plant Quarantine Agency for diagnosis. Each cat tissue sample was homogenized, and centrifuged at 13,000 rpm for $1 \mathrm{~min}$, and the supernatants were used for antigen test by PCR. Sera were obtained from whole blood by centrifugation at 3,000 $\times \mathrm{g}, 5 \mathrm{~min}$. In addition, sera from domestic $(\mathrm{n}=438)$ and stray $(\mathrm{n}=261)$ dogs were also separated from blood clot samples by centrifuging at 3,000 $\times \mathrm{g}, 5 \mathrm{~min}$. However, the sera could not be obtained from 105 and 3 of whole blood samples from domestic and stray cats, respectively due to small amount and separation problem. Therefore, total number of sera from domestic dogs, domestic cats, stray dogs, and stray cats were 2,412, 909, 947, and 403, respectively. Whole bloods, sera, and feces were stored at $4^{\circ} \mathrm{C}$ until testing, and tissues at $-20^{\circ} \mathrm{C}$ until testing.
ELISA

All sera were tested using a commercial ELISA kit (ID Screen $^{\circledR}$ Toxoplasmosis Indirect Multi-species Kit; IDvet, Grabels, France) to detect antibodies against the P30 protein of $T$. gondii. All sera samples were injected into the corresponding wells. And then the other procedures, such as washing the plates, and adding a multi-species peroxidase conjugate, substrate (3,3',5,5'-tetramethylbenzidine), and stop solution, were followed by the manufacturer's instruction. For each sample, optical density (OD) values were measured at $450 \mathrm{~nm}$. The positive percentage of the sample $(\mathrm{S} / \mathrm{P} \%)$ was calculated according to the manufacturer's instruction and used to determine the seroprevalence. It is positive if the value of $\mathrm{S} / \mathrm{P} \%$ is more than 70 for dogs and 50 for cats, and negative in both cases if it is less than 40 .

\section{PCR and real-time PCR}

DNA was extracted from blood and homogenized tissue samples according to the manufacturer's instructions of Maxwell ${ }^{\circledR}$ RSC Whole Blood and Viral TNA Kit (Promega, Madison, Wisconsin, USA), respectively, and Maxwell ${ }^{\circledR}$ RSC Instrument (Promega). The cartridges to be used were placed in the deck tray(s). Each cartridge in the deck tray(s) were placed with well \#1 (the largest well in the cartridge) facing away from the elution tubes. All sealing tape and any residual adhesive were removed before placing cartridges in the instrument. Blood samples or tissue lysates were transferred to well \#1 of the cartridge. An empty elution tube was placed into the elution tube position for each cartridge in the deck tray. Sixty $\mu \mathrm{l}$ of elution buffer was added to the bottom of each elution tube. And then Maxwell ${ }^{\circledR}$ RSC Instrument was setup and performed. T. gondii oocysts were isolated from cat fecal samples using the sugar floatation method. After washing with $1 \mathrm{~g}$ of feces in distilled water (D.W.), samples were mixed with sugar solution and suspended for $1 \mathrm{hr}$. The sugar solution was prepared by dissolving $454 \mathrm{~g}$ of sugar in D.W. $355 \mathrm{ml}$ while heating, and adding $6 \mathrm{ml}$ of $37 \%$ formaldehyde solution. DNA was extracted from $500 \mu \mathrm{l}$ of supernatant from the feces sample using QIAamp ${ }^{\circledR}$ Fast DNA Stool Mini Kit (QIAGEN, Stockach, Germany). The extracted DNA was stored at $-20^{\circ} \mathrm{C}$ until use. DNA was analyzed for the amplification of $B 1$ gene in $T$. gondii by CFX Connect ${ }^{\mathrm{TM}}$ and $\mathrm{CFX}{ }^{\mathrm{TM}}{ }^{\mathrm{T}}$ real-time PCR system (Bio-Rad, Hercules, California, USA) [25,26]. A positive control DNA was extracted by T. gondii RH strain tachyzoites cultured in vitro. Further, $2 \mu \mathrm{l}$ of extracted DNA was added with 
Table 1. Primers and annealing conditions of PCR, nested PCR and real-time PCR for Toxoplasma gondii B1 gene

\begin{tabular}{|c|c|c|c|c|}
\hline PCR & Primer & Sequence $\left(5^{\prime} \rightarrow 3^{\prime}\right)$ & Annealing $\left({ }^{\circ} \mathrm{C} / \mathrm{sec}\right)$ & Amplicon size (bp) \\
\hline \multirow[t]{2}{*}{ PCR } & $\mathrm{T} 1$ & GGAACTGCATCCGTTCATGAG & $50 / 30$ & 501 \\
\hline & $\mathrm{T} 2$ & CAGACGAATCACGGAACTG & & \\
\hline \multirow[t]{3}{*}{ Phylogeny } & Primary PCR & Tg1: TGTTCTGTCCTATCGCAACG & $48 / 40$ & 516 \\
\hline & & Tg2: ACGGATGCAGTTCCTाTCTG & & \\
\hline & Nested reaction & $\begin{array}{l}\text { Tg3: TCTTCCCAGACGTGGATTC } \\
\text { Tg4: CTCGACAATACGCTGCTTGA }\end{array}$ & $56 / 60$ & \\
\hline \multirow[t]{3}{*}{ rt-PCR } & TOXO-P & FAM-TCTGTGCAACTTTGGTGTATTCGCAG-TAMRA & $50 / 30$ & \\
\hline & TOXO-F & TCСССTCTGCTGGCGAAAAGT & & \\
\hline & TOXO-R & AGCGTTCGTGGTCAACTATCGATTG & & \\
\hline
\end{tabular}

$10 \mu \mathrm{l}$ of iQTM Supermix (Bio-Rad), $1 \mu \mathrm{l}$ of mixed primer and probe, and $7 \mu$ l of D.W., and PCR was performed at $95^{\circ} \mathrm{C}$ for 10 min, 40 cycles of $95^{\circ} \mathrm{C}$ for $15 \mathrm{sec}$ and $60^{\circ} \mathrm{C}$ for $1 \mathrm{~min}$ (Table 1).

\section{Phylogenetic analysis}

The $B 1$ gene amplification of positive samples in real-time PCR was performed by nested PCR assay for phylogenetic analysis (Table 1) [27]. The mixture containing AccuPower ${ }^{\circledR}$ PCR PreMix (Bioneer, Daejeon, Korea) was a total volume of $20 \mu \mathrm{l}$ containing $2 \mu \mathrm{l}$ of extracted DNA, $1 \mu \mathrm{l}$ of each primer, and $16 \mu \mathrm{l}$ D.W. for the first reaction, followed by 35 cycles of $94^{\circ} \mathrm{C}$ for $30 \mathrm{sec}, 48^{\circ} \mathrm{C}$ for $40 \mathrm{sec}$ and $72^{\circ} \mathrm{C} 45 \mathrm{sec}$. The nested reaction was performed in $20 \mu \mathrm{l}$ of the solution containing 1 $\mu \mathrm{l}$ of the first reaction product, $1 \mu \mathrm{l}$ of each primer, and $17 \mu \mathrm{l}$ D.W., followed by 35 cycles of $94^{\circ} \mathrm{C}$ for $45 \mathrm{sec}, 56^{\circ} \mathrm{C}$ for $1 \mathrm{~min}$ and $72^{\circ} \mathrm{C}$ for $90 \mathrm{sec}$. The eluted DNA samples were sent for sequencing (Macrogen Inc., Seoul, Korea). Each sequence of amplified gene fragment was analysed by NCBI BLAST software. The aligned dataset of $B 1$ gene of $T$. gondii was analysed by Molecular Evolution Genetics Analysis (MEGA) version 7.0 software. Phylogenetic tree of aligned sequences was constructed using the neighbor-joining method [28].

\section{Statistical analysis}

Seroprevalences and antigen prevalences were calculated from the proportion of positive results of those tested by ELISA and PCR, respectively, and were presented with 95\% confidence intervals (CIs). We used Microsoft Excel 2019 software and SPSS (v25.0) to perform descriptive statistical analysis data: the difference in positive rates according to domestic and stray groups in dogs and cats by Student's t-test and Chi-square test. Differences were considered significant at $p<0.05$.

\section{RESULTS}

In Korea, the seroprevalence of T. gondii in dogs and cats was $1.6 \%(95 \% \mathrm{CI}=1.59-1.61)$ and $5.9 \%(95 \% \mathrm{CI}=5.85-5.94)$, respectively (Table 2). seroprevalence of stray cats was the highest $(14.1 \%, 95 \% \mathrm{CI}=13.9-14.3)\left(\chi^{2}=14.44, d f=1, P=0.0001\right)$, followed by stray dogs $(5.6 \%, 95 \% \mathrm{CI}=5.55-5.65)$, domestic cats $(2.3 \%, 95 \% \mathrm{CI}=2.27-2.33)$, and domestic dogs $(0.04 \%$, $95 \% \mathrm{CI}=0.038-0.042$ ) (Table 2). Jeju (55.6\%) revealed the highest seroprevalence in Korea. Seroprevalence in stray cats in both Daejeon-Chungnam (17.3\%) and Seoul-Gyeonggi-Incheon (17.2\%) was greater than $10 \%$. In contrast, domestic cats were found only in Seoul-Gyeonggi-Incheon (2.3\%) and Gangwon (20.0\%). Seroprevalence of T. gondii in stray dogs was the highest in Jeonbuk region (9.1\%).Seroprevalence greater than 5.0\% were Seoul-Gyeonggi-Incheon (8.8\%), Jeju (8.1\%), DaejeonChungnam (7.2\%), and Gwangju-Jeonnam (6.7\%). The antibody positive reactor of domestic dogs was the only one of 2,412 samples tested in Jeju (Table 2).

In Korea, antigen prevalence of dogs was 0.3\% (95\% $\mathrm{CI}=0.296-0.304)$ and that of cat was $0.2 \%(95 \% \mathrm{CI}=0.198$ $0.202)$ (Table 3; Figs. 1, 2). Antigen prevalence of stray cats was the highest $(0.5 \%, 95 \% \mathrm{CI}=0.49-0.51)\left(\chi^{2}=5.95, d f=1\right.$, $P=0.015)$, followed by domestic dogs $(0.4 \%, 95 \% \mathrm{CI}=0.394$ $0.406)$, stray dogs $(0.2 \%, 95 \% \mathrm{CI}=0.19-0.21)$, and domestic cats $(0.1 \%, 95 \% \mathrm{CI}=0.098-0.102)$ (Table 2$)$. In all regions except Daegu-Gyeongbuk, which showed $1.0 \%$ antigen-positive rate, dog antigen-positive rate was less than $1.0 \%$. Among domestic dogs, antigen-positive areas were Seoul-Gyeonggi- 
Table 2. Antibody prevalence of toxoplasmosis in dogs and cats in Korea during 2017-2019

\begin{tabular}{|c|c|c|c|c|c|c|}
\hline \multirow{3}{*}{ Region } & \multicolumn{6}{|c|}{ Positive/Test } \\
\hline & \multicolumn{3}{|c|}{ Dog } & \multicolumn{3}{|c|}{ Cat } \\
\hline & Domestic & Stray & Subtotal & Domestic & Stray & Subtotal \\
\hline Seoul-Gyeonggi-Incheon & $0 / 2,112$ & $15 / 170$ & $15 / 2,282$ & 20/876 & $10 / 58$ & $30 / 934$ \\
\hline Gangwon & 0/91 & $2 / 136$ & $2 / 227$ & $1 / 5$ & - & $1 / 5$ \\
\hline Daejeon-Chungnam & 0/55 & $6 / 83$ & $6 / 138$ & $0 / 2$ & 23/133 & 23/135 \\
\hline Chungbuk & - & $0 / 19$ & 0/19 & $0 / 1$ & - & $0 / 1$ \\
\hline Jeonbuk & $0 / 16$ & $4 / 44$ & $4 / 60$ & $0 / 1$ & - & $0 / 1$ \\
\hline Daegu-Gyeoungbuk & $0 / 37$ & $1 / 76$ & $1 / 113$ & $0 / 10$ & $4 / 166$ & $4 / 176$ \\
\hline Gwangju-Jeonnam & 0/17 & $8 / 119$ & $8 / 136$ & - & 0/10 & 0/10 \\
\hline Busan-Ulsan-Gyeongnam & $0 / 51$ & $6 / 163$ & $6 / 214$ & $0 / 12$ & - & $0 / 12$ \\
\hline Jeju & $1 / 33$ & $11 / 136$ & $12 / 169$ & $0 / 2$ & $20 / 36$ & $20 / 38$ \\
\hline Unknown & - & $0 / 1$ & $0 / 1$ & - & - & - \\
\hline Total & $1 / 2,412$ & $53 / 947$ & $54 / 3,359$ & $21 / 909$ & $57 / 403$ & $78 / 1,312$ \\
\hline$P$-value* & & $<0.0001$ & & & $<0.0001$ & \\
\hline
\end{tabular}

*Student's $t$-test. $p$-value compared between domestic and stray groups of dogs and cats.

Table 3. Antigen prevalence of Toxoplasma gondii in dogs and cats in Korea

\begin{tabular}{|c|c|c|c|c|c|c|}
\hline \multirow{3}{*}{ Region } & \multicolumn{6}{|c|}{ Positive/Test } \\
\hline & \multicolumn{3}{|c|}{ Dog } & \multicolumn{3}{|c|}{ Cat } \\
\hline & Domestic & Stray & Subtotal & Domestic & Stray & Subtotal \\
\hline Seoul-Gyeonggi-Incheon & $1 / 1,250$ & $0 / 81$ & $1 / 1,331$ & $3 / 2,934$ & $2 / 261$ & $5 / 3,195$ \\
\hline Gangwon & $4 / 331$ & 0/105 & $4 / 436$ & 0/9 & $0 / 23$ & $0 / 32$ \\
\hline Daejeon-Chungnam & 0/86 & $0 / 74$ & $0 / 160$ & $0 / 17$ & $2 / 298$ & $2 / 315$ \\
\hline Chungbuk & 0/84 & $0 / 24$ & $0 / 108$ & $0 / 12$ & - & $0 / 12$ \\
\hline Jeonbuk & $0 / 8$ & $0 / 45$ & $0 / 53$ & $0 / 11$ & $0 / 9$ & $0 / 20$ \\
\hline Daegu-Gyeoungbuk & $0 / 25$ & $1 / 74$ & $1 / 99$ & $0 / 32$ & $0 / 266$ & $0 / 298$ \\
\hline Gwangju-Jeonnam & $0 / 8$ & $0 / 81$ & 0/89 & $0 / 4$ & $0 / 48$ & $0 / 77$ \\
\hline Busan-Ulsan-Gyeongnam & $1 / 117$ & $0 / 108$ & $1 / 225$ & $0 / 19$ & $0 / 51$ & $0 / 70$ \\
\hline Jeju & $1 / 65$ & $0 / 94$ & $1 / 159$ & $0 / 2$ & $0 / 118$ & $0 / 120$ \\
\hline Unknown & - & - & $0 / 1$ & - & $3 / 318$ & $3 / 318$ \\
\hline Total & $7 / 1,974$ & $1 / 686$ & $8 / 2,660$ & $3 / 3,040$ & $7 / 1,392$ & $10 / 4,432$ \\
\hline$P$-value ${ }^{*}$ & & 0.291 & & & 0.041 & \\
\hline
\end{tabular}

*Student's $t$-test. $p$-value compared between domestic and stray groups of dogs and cats.

Incheon (0.1\%), Gangwon (1.2\%), Busan-Ulsan-Gyeongnam $(0.9 \%)$, and Jeju (1.5\%). Antigenic positivity of stray dogs was the only 1 in the Daegu-Gyeongbuk region (1.4\%). Interestingly, domestic dogs' antigen-positive rate was $0.4 \%$ (95\% $\mathrm{CI}=0.394-0.406 ;)$, which was higher than that $(0.2 \%, 95 \%$ $\mathrm{CI}=0.187-0.213 ; 1 / 686)$ of stray dogs. Domestic cats showed $0.1 \%(95 \% \mathrm{CI}=0.098-0.102)$ antigen-positive rate, which were from Seoul-Gyeonggi-Incheon region, and stray cats showed $0.5 \%$ (95\% CI $=0.49-0.51)$ antigen-positive rate. Antigen-positive stray cats were found in Seoul-Gyeonggi-Incheon (0.8\%), and Chungcheongnam-do $(0.7 \%, 2 / 298)$, and 3 out of 318 stray cats were unknown (0.9\%).

All 5 B1 gene positive samples were obtained from stray cats, which were 18D174 (Stray cat spleen), 4_5SJ11 (Stray cat feces), 19Q130 (Stray cat gut), 18Q89 (Stray cat heart), and 18D174 (Stray cat brain) (Fig. 3). Phylogenetic analysis showed that these samples belong to the same group as the highly pathogenic RH strain (Type I) and the moderately pathogenic VEG strain (Type III) (Fig. 3). Five B1 gene positive samples belonging to the Type I/III group were not differentiated further (Fig. 3). Genetic difference of B1 gene between Type I and Type III was only $0.2 \%$. Five $B 1$ gene positive samples were collected in 2018 and 2019. Samples obtained in 2018 were 18Q89 and 18D174, which were collected in June and July, respectively. Samples taken in 2019 were 4_5SJ11 and 19Q130, which were collected in April and July, respectively. 
A

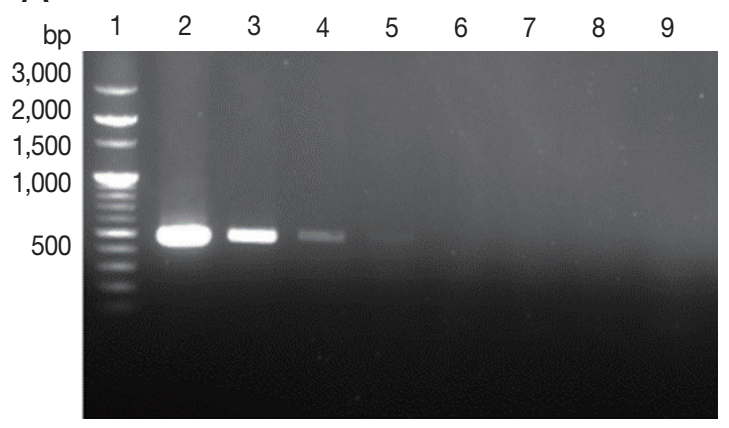

B

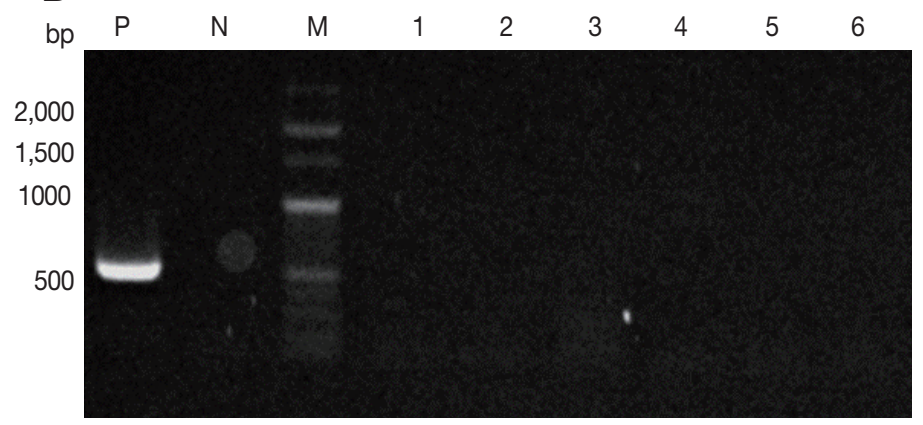

Fig. 1. PCR on Toxoplasma gondii B1 gene. (A) Sensitivity of B1 gene PCR. Lane 1, DNA size marker; Lanes 2-9, dilution of T. gondii tachyzoites from $10^{4}$ to $10^{-3}$. (B) Specificity of B1 gene PCR. P, positive (T. gondii); N, negative; M, DNA size marker. Lane 1, Neospora caninum; 2, Ehrlichia chaffeensis; 3, Ehrlichia canis; 4, Anaplasma phagocytophilum; 5, Brucella abortus; 6, Coxiella burnetii.

A

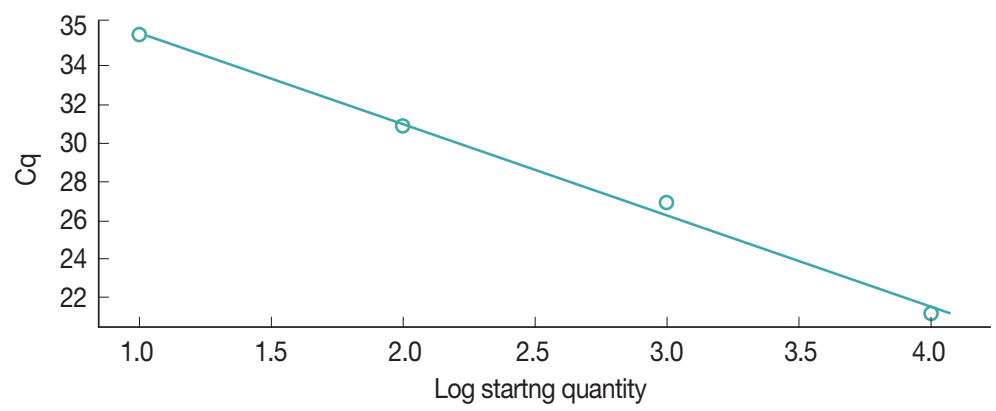

\begin{tabular}{cc}
\hline Tachyzoites $(/ \mu l)$ & $\mathrm{Ct}$ \\
\hline $1 \times 10^{4}$ & 21.34 \\
$1 \times 10^{3}$ & 26.93 \\
$1 \times 10^{2}$ & 30.90 \\
$1 \times 10^{1}$ & 35.60 \\
$1 \times 10^{0}$ & - \\
$1 \times 10^{-1}$ & - \\
$1 \times 10^{-2}$ & - \\
$1 \times 10^{-3}$ & - \\
\hline
\end{tabular}

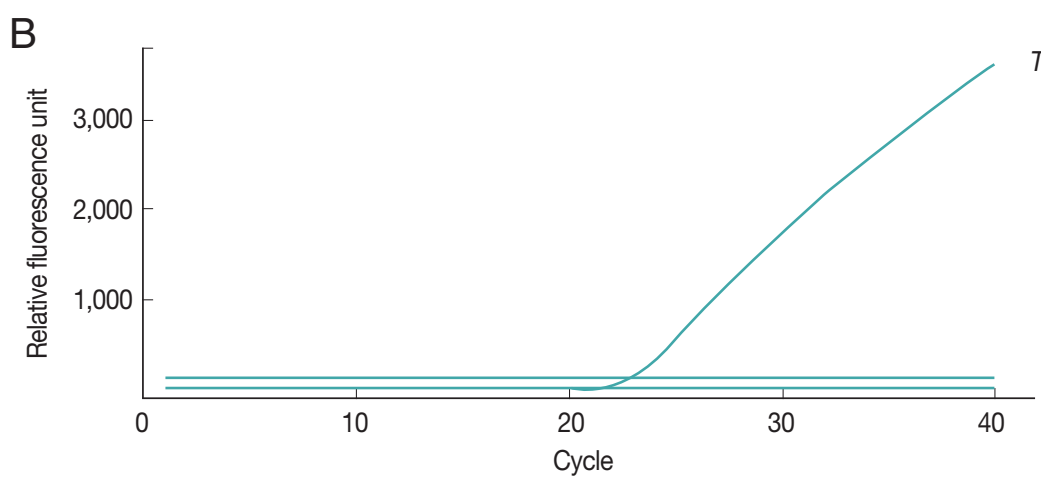

Toxoplasma gondii

Negative control Neospora caninum Ehrlichia chaffeensis Ehrlichia canis Anaplasma phagocytophilum Brucella abortus Coxiella burnetii

Fig. 2. Real-time PCR of Toxoplasma gondii B1 gene. (A) Sensitivity. (B) Specificity.

No changes in genetic lineage between 2018 and 2019 were observed between the positive samples. The positive samples had the highest genetic similarity to the $B 1$ gene present in the causative agent of Korean rabbit origin (KF038120), aborted sheep fetus from Iran (DQ789361), brain (Neofelis nebulosa and Rattus rattus) in Thailand (KF425006) (Fig. 3).

\section{DISCUSSION}

In this study, we investigated the prevalence of antibodies and antigens in Korean dogs and cats, and the genetic relationship between Korean Toxoplasma gondii was compared. In Korea, the seroprevalence of toxoplasmosis in dogs and cats was 1.6 and $6.0 \%$, respectively. Additionally, the antigen prevalence in dogs and cats was $0.3 \%$ and $0.2 \%$, respectively. Notably, the seroprevalence of stray cats was $14.1 \%$, the highest among dogs and cats in Korea. Additionally, 5 T. gondii B1 gene positive samples were found to be in Type I/III group, in which there were both the highly pathogenic RH strain, Type I and the moderately pathogenic VEG strain, Type III (Fig. 3). 


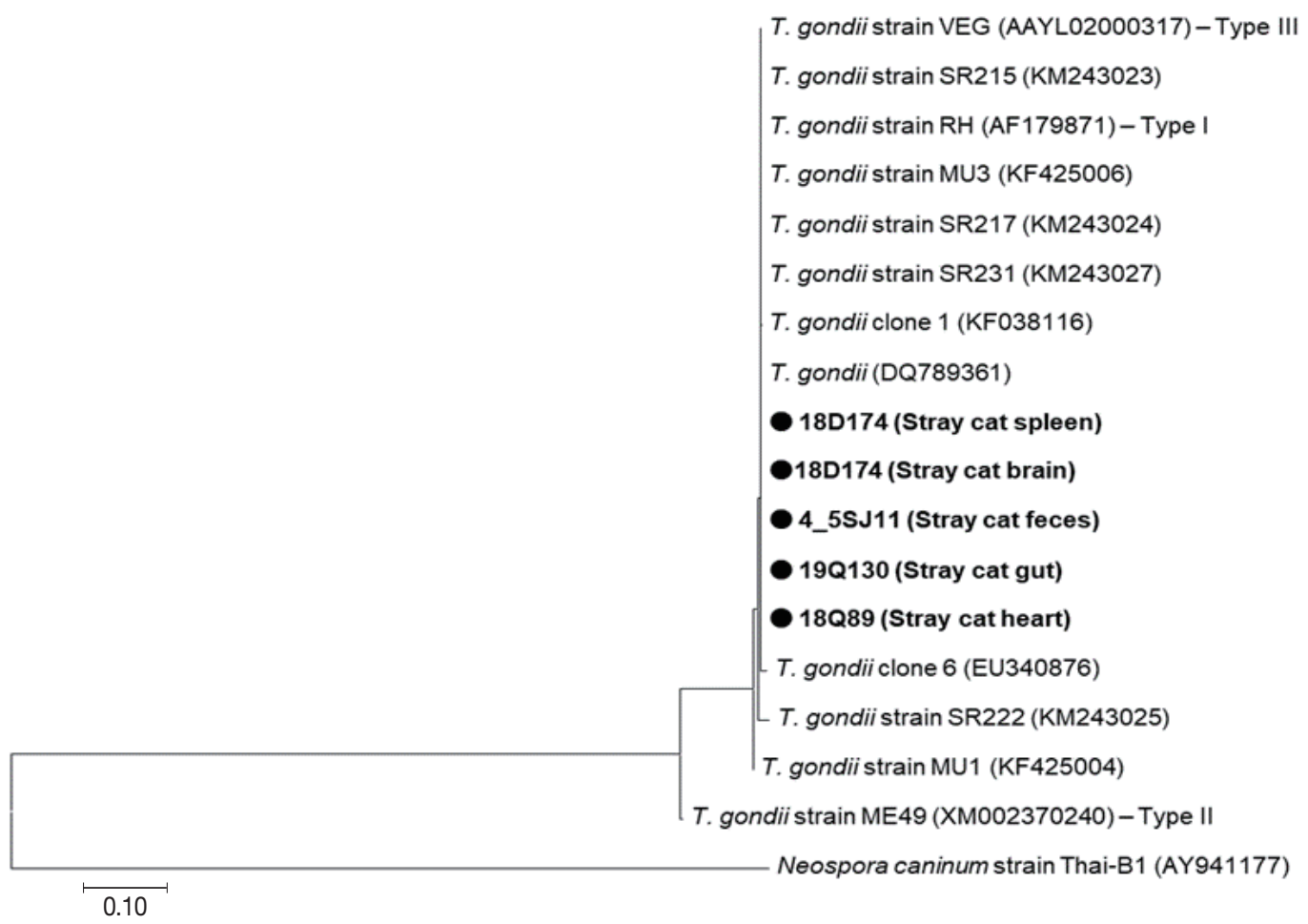

Fig. 3. Phylogenetic tree of $B 1$ gene of 5 Toxoplasma gondii samples from stray cats in Korea. Phylograms were generated by neighborjoining analysis with 1,000 bootstrapped replicates. GenBank accession number of $T$. gondii is labeled on each line. Sequences of this study are closed circles. Scale bar indicates nucleotide substitution per site.

The seroprevalence in Korean stray cats showed no significant differences by year, and ranged from $8.1 \%$ (2008, LAT) to $16.0 \%$ (1999, LAT) [10,19-21]. This finding might be attributed to regional differences, as well as differences in the test method used. Although the toxoplasma antibody was not detected in Korean domestic cats in the 2010 survey [21], the seroprevalence of toxoplasmosis in domestic cats in our study was 2.3\% (Table 2). Notably, our study is the first to report the presence of toxoplasma antibodies in domestic cats in Korea, emphasizing that additional hygienic practices must be developed to minimize public health concerns in Korea. Cat antibody levels in Thailand were relatively low, ranging from $4.8 \%$ to $11.0 \%$ $[11,29]$. Japanese seroprevalence of stray cats was $5.6 \%$ to $15.5 \%$, similar to Korean prevalence [8]. Feline antibody levels in Spain, USA, China, Poland, Belgium, and Portugal were $27.2 \%, 48.0 \%, 63.2 \%, 68.1 \%, 70.2 \%$, and $72.4 \%$, respectively [12,14-18,30], highlighting that toxoplasmosis cat infections are widespread in these countries. The cause of high seroprevalence in these countries seems to be closely related to the ecological habits of stray cats, such as poor hygiene, high temperature, and high humidity of the environment. The seropreva- lence of Korean stray and domestic dogs reported in this study was significantly different from the previous survey report, in which the seroprevalence of stray and domestic dogs was reported as $18.5 \%$ and $5.1 \%$, respectively [22]. This may be due to the use of a more specific diagnostic method in this study than the LAT test, the sampling areas and ages, and the collecting periods [28]. The seroprevalence of stray dogs in Japan was lower than that of Korea [8], and consequently the environmental contamination of $T$. gondii is likely lower in Japan than in Korea. The seroprevalence of T. gondii in dogs in China ranged from $21 \%$ to $51.9 \%$ and $69.8 \%$ in Brazil $[9,14,31,32]$. Therefore, the environmental toxoplasma contamination of these countries as well as the rate of cat toxoplasmosis infection, is expected to be very high.

Antigen prevalence among stray cats in the present study was $0.5 \%$, which was significantly lower than the values from previous studies, which ranged from $4.7 \%$ to $30.6 \%$ $[10,20,21,23]$. The large range in the positive rates reported between studies can be attributed, at least in part, to differences in regions from which the samples were derived. The antigen prevalence in Scotland and China were reported at 19.2\% and 
$52.6 \%$, respectively $[14,33]$. Therefore, these countries of highly antigen prevalence might be contaminated with Toxoplasma gondii in the environment, and then the warm-blood mammals including humans could be infected more easily by environmental and food contaminated T. gondii. In China, which showed high antigen-positive rates in cats, the rate of dog antigens was also relatively high, ranging from $3.7 \%$ to $8.6 \%$ $[9,14]$. In this study, antigen prevalence of T. gondii of domestic and stray dogs and cats in South Korea was very low as much as that of Japan. Based on these results, the infection risk might be low, but the seroprevalence was still high in stray cats and dogs. Therefore, the hygienic handling of pet dogs and cats will be performed steadily to prevent this zoonotic agent.

The phylogenetic analysis of $5 \mathrm{~B} 1$ gene-positive samples from stray cats showed the highest homology with $B 1$ genes in Indians, American mussels, Thai black rats, and Korean rabbit toxoplasma [34,35]. These strains were all in the same phylogenetic group as the highly pathogenic Type I and moderately pathogenic Type III strain (Type I/III group). Further new targets for phylogenetic analysis were needed to differentiate Type I and Type III clearly. According to a report from China [9], the results of genetic analysis of the dog-derived toxoplasma strains all showed high similarity to the pathogenic Type I strain. On the other hand, in Korea, the result of genetic analysis of two strains reported by Jung et al. [23] was corresponded to the group of low virulent Type II. In this study, all 5 T. gondii were grouped as Type I/III strain (Fig. 3). This difference is presumably due to the different regions taken. Based on our findings, we demonstrated that stray cat isolates in Korea are mixed with high pathogenic Type I, moderate pathogenic Type III, or low pathogenic Type II depending on the regions. Genotypes identified in various regions of China - Guangdong, Hunan, Hubei, Anhui, and Guizhou province - have been identified as low virulent Chinese 1 genotypes that differ from Types I, II, and III [14]. Notably, genetic analysis of a larger sample size of isolates in the future studies would likely reveal novel Korean toxoplasma genotypes.

In Korea, the reported seroprevalence of toxoplasmosis in humans varies among different studies, ranging from $0.9 \%$ to $17.0 \%$ [36-42]. This trend suggests that the seroprevalence of human toxoplasmosis is increasing in Korea, as is the case in the USA [30], where there is a high amount of livestock consumption. In particular, the prevalence of infection in immunodeficiency diseases such as HIV/AIDS patients [43], pregnant women [44], and the elderly [45] increases the necessity of fundamental prevention in animals against toxoplasma, including cats and dogs. As highlighted by the results of our study, measures to prevent infection of stray cats should be strengthened in order to minimize zoonotic toxoplasmosis in Korea. On the other hand, dogs are also highly likely to be infected or mechanically spread from toxoplasmosis from feces contaminated with the environment [6-9]. Therefore, proper management of stray and domestic animals should be prioritized as a factor towards improving overall public health.

\section{ACKNOWLEDGMENT}

This research was supported by a grant (Project Code No. N-1543081-2017-19-0101) from Research of Animal and Plant Quarantine Agency, South Korea.

\section{CONFLICT OF INTEREST}

The authors declare that there is no conflict of interests regarding the publication of this article.

\section{REFERENCES}

1. Animal Protection Management System. 2018 Companion Animal Protection and Welfare Survey [Internet]. Gimcheon, Korea: Animal and Plant Quarantine Agency. Available from: https:// www.animal.go.kr/front/community/show.do?boardId=boardI D03\&page $=1$ \&pageSize $=10$ \& keyword $=\&$ column $=\&$ menuNo $=7$ $000000005 \&$ seq $=11032$ (in Korean).

2. Ferra B, Holec-Gąsior L, Gatkowska J, Dziadek B, Dzitko K. Toxoplasma gondii recombinant antigen AMA1: diagnostic utility of protein fragments for the detection of IgG and IgM antibodies. Pathogens 2020; 9: 43.

3. Djurković-Djaković O, Dupouy-Camet J, Van der Giessen J, Dubey JP. Toxoplasmosis: overview from a one health perspective. Food Waterborne Parasitol 2019; 15: e00054.

4. Montazeri M, Mikaeili Galeh T, Moosazadeh M, Sarvi S, Dodangeh S, Javidnia J, Sharif M, Daryani A. The global serological prevalence of Toxoplasma gondii in felids during the last five decades (1967-2017): a systematic review and meta-analysis. Parasit Vectors 2020; 13: 82.

5. Amouei A, Sarvi S, Sharif M, Aghayan SA, Javidnia J, Mizani A, Moosazadeh M, Shams N, Hosseini SA, Hosseininejad Z, Nayeri Chegeni T, Badali H, Daryani A. A systematic review of Toxoplasma gondii genotypes and feline: Geographical distribution trends. Transbound Emerg Dis 2020; 67: 46-64.

6. Lindsay DS, Dubey JP, Butler JM, Blagburn BL. Mechanical transmission of Toxoplasma gondii oocysts by dogs. Vet Parasitol 1997; 
73: 27-33.

7. Frenkel JK, Lindsay DS, Parker BB, Dobesh M. Dogs as possible mechanical carriers of Toxoplasma, and their fur as a source of infection of young children. Int J Infect Dis 2003; 7: 292-293.

8. Oi M, Yoshikawa S, Maruyama S, Nogami S. Comparison of Toxoplasma gondii seroprevalence in shelter cats and dogs during 1999-2001 and 2009-2011 in Tokyo, Japan. PLoS One 2015; 10: e0135956.

9. Jiang HH, Li MW, Xu MJ, Cong W, Zhu XQ. Prevalence of Toxoplasma gondii in dogs in Zhanjiang, Southern China. Korean J Parasitol 2015; 53: 493-496.

10. Lee SE, Kim NH, Chae HS, Cho SH, Nam HW, Lee WJ, Kim SH, Lee JH. Prevalence of Toxoplasma gondii infection in feral cats in Seoul, Korea. J Parasitol 2011; 97: 153-155.

11. Jittapalapong $S$, Inpankaew T, Pinyopanuwat N, Chimnoi W, Kengradomkij C, Wongnarkpet S, Maruyama S, Lekkla A, Sukthana Y. Epidemiology of Toxoplasma gondii infection of stray cats in Bangkok, Thailand. Southeast Asian J Trop Med Public Health 2010; 41: 13-18.

12. Miro G, Montoya A, Jimenez S, Frisuelos C, Mateo M, Fuentes I. Prevalence of antibodies to Toxoplasma gondii and intestinal parasites in stray, farm and household cats in Spain. Vet Parasitol 2004; 126: 249-255.

13. Barros M, Cabezon O, Dubey JP, Almeria S, Ribas MP, Escobar LE, Ramos B, Medina-Vogel G. Toxoplasma gondii infection in wild mustelids and cats across an urban-rural gradient. PLoS One 2018; 13: e0199085.

14. Li YN, Nie X, Peng QY, Mu XQ, Zhang M, Tian MY, Min SJ. Seroprevalence and genotype of Toxoplasma gondii in pigs, dogs and cats from Guizhou province, Southwest China. Parasit Vectors 2015; 8: 214.

15. Michalski MM, Platt-Samoraj A, Mikulska-Skupien E. Toxoplasma gondii antibodies in domestic cats in Olsztyn urban area, Poland. Wiad Parazytol 2010; 56: 277-279.

16. De Craeye S, Francart A, Chabauty J, De Vriendt V, Van Gucht S, Leroux I, Jongert E. Prevalence of Toxoplasma gondii infection in Belgian house cats. Vet Parasitol 2008; 157: 128-132.

17. Dorny P, Speybroeck N, Verstraete S, Baeke M, De Becker A, Berkvens D, Vercruysse J. Serological survey of Toxoplasma gondii, feline immunodeficiency virus and feline leukaemia virus in urban stray cats in Belgium. Vet Rec 2002; 151: 626-629.

18. Lopes AP, Cardoso L, Rodrigues M. Serological survey of Toxoplasma gondii infection in domestic cats from northeastern Portugal. Vet Parasitol 2008; 155: 184-189.

19. Sohn WM, Nam HW. Western blot analysis of stray cat sera against Toxoplasma gondii and the diagnostic availability of monoclonal antibodies in sandwich-ELISA. Korean J Parasitol 1999; 37: 249-256.

20. Kim HY, Kim YA, Kang S, Lee HS, Rhie HG, Ahn HJ, Nam HW, Lee SE. Prevalence of Toxoplasma gondii in stray cats of Gyeonggido, Korea. Korean J Parasitol 2008; 46: 199-201.

21. Lee SE, Kim JY, Kim YA, Cho SH, Ahn HJ, Woo HM, Lee WJ, Nam HW. Prevalence of Toxoplasma gondii infection in stray and household cats in regions of Seoul, Korea. Korean J Parasitol 2010; 48: 267-270.

22. Nguyen TT, Choe SE, Byun JW, Koh HB, Lee HS, Kang SW. Seroprevalence of Toxoplasma gondii and Neospora caninum in dogs from Korea. Acta Parasitol 2012; 57: 7-12.

23. Jung BK, Lee SE, Lim H, Cho J, Kim DG, Song H, Kim MJ, Shin $\mathrm{EH}$, Chai JY. Toxoplasma gondii B1 gene detection in feces of stray cats around Seoul, Korea and genotype analysis of two laboratory-passaged Isolates. Korean J Parasitol 2015; 53: 259-263.

24. Ahn KS, Ahn AJ, Park SI, Sohn WM, Shim JH, Shin SS. Excretion of Toxoplasma gondii oocysts from feral cats in Korea. Korean J Parasitol 2019; 57: 665-670.

25. Stiles J, Prade R, Greene C. Detection of Toxoplasma gondii in feline and canine biological samples by use of the polymerase chain reaction. Am J Vet Res 1996; 57: 264-267.

26. Lin MH, Chen TC, Kuo TT, Tseng CC, Tseng CP. Real-time PCR for quantitative detection of Toxoplasma gondii. J Clin Microbiol 2000; 38: 4121-4125.

27. Grigg ME, Boothroyd JC. Rapid identification of virulent type I strains of the protozoan pathogen Toxoplasma gondii by PCR-restriction fragment length polymorphism analysis at the $\mathrm{B} 1$ gene. J Clin Microbiol 2001; 39: 398-400.

28. Thakur R, Sharma R, Aulakh RS, Gill JPS, Singh BB. Prevalence, molecular detection and risk factors investigation for the occurrence of Toxoplasma gondii in slaughter pigs in North India. BMC Vet Res 2019; 15: 431.

29. Jittapalapong S, Nimsupan B, Pinyopanuwat N, Chimnoi W, Kabeya H, Maruyama S. Seroprevalence of Toxoplasma gondii antibodies in stray cats and dogs in the Bangkok metropolitan area, Thailand. Vet Parasitol 2007; 145: 138-141.

30. Dubey JP, Jones JL. Toxoplasma gondii infection in humans and animals in the United States. Int J Parasitol 2008; 38: 12571278.

31. Zhang H, Zhou DH, Chen YZ, Lin RQ, Yuan ZG, Song HQ, Li SJ, Zhu XQ. Antibodies to Toxoplasma gondii in stray and household dogs in Guangzhou, China. J Parasitol 2010; 96: 671-672.

32. Valadas S, Minervino AH, Lima VM, Soares RM, Ortolani EL, Gennari SM. Occurrence of antibodies anti-Neospora caninum, anti-Toxoplasma gondii, and anti-Leishmania chagasi in serum of dogs from Para State, Amazon, Brazil. Parasitol Res 2010; 107: 453-457.

33. Bennett AD, Gunn-Moore DA, Brewer M, Lappin MR. Prevalence of Bartonella species, haemoplasmas and Toxoplasma gondii in cats in Scotland. J Feline Med Surg 2011; 13: 553-557.

34. Shapiro K, VanWormer E, Aguilar B, Conrad PA. Surveillance for Toxoplasma gondii in California mussels (Mytilus californianus) reveals transmission of atypical genotypes from land to sea. Environ Microbiol 2015; 17: 4177-4188.

35. Shin HG, Lee SE, Hong SH, Kim SM, Choi YK, Park HJ, Seo KW, Song KH. Prevalence of Toxoplasma gondii infection in rabbits of Korea by serological tests and nested polymerase chain reaction. J Vet Med Sci 2013; 75: 1609-1613.

36. Song KJ, Shin JC, Shin HJ, Nam HW. Seroprevalence of toxo- 
plasmosis in Korean pregnant women. Korean J Parasitol 2005; 43: 69-71.

37. Han K, Shin DW, Lee TY, Lee YH. Seroprevalence of Toxoplasma gondii infection and risk factors associated with seropositivity of pregnant women in Korea. J Parasitol 2008; 94: 963-965.

38. Choi WY, Nam HW, Youn JH, Kim DJ, Kong Y, Kang SY, Cho SY. Detection of antibodies in serum and cerebrospinal fluid to Toxoplasma gondii by indirect latex agglutination test and enzyme-linked immunosorbent assay. Kisaengchunghak Chapchi 1992; 30: 83-90.

39. Shin DW, Cha DY, Hua QJ, Cha GH, Lee YH. Seroprevalence of Toxoplasma gondii infection and characteristics of seropositive patients in general hospitals in Daejeon, Korea. Korean J Parasitol 2009; 47: 125-130.

40. Yang HJ, Jin KN, Park YK, Hong SC, Bae JM, Lee SH, Choi HS, Hwang HS, Chung YB, Lee NS, Nam HW. Seroprevalence of toxoplasmosis in the residents of Cheju island, Korea. Korean J Parasitol 2000; 38: 91-93.

41. Hong SJ, Chong CK, Lee K, Kim TS, Hong YP, Ahn HJ, Kim HY,
Ko AR, Kim YJ, Nam HW. Maintained seroprevalence of toxoplasmosis among the residents of Jeju island, Korea. Korean J Parasitol 2011; 49: 309-311.

42. Ahn HJ, Cho PY, Ahn SK, Kim TS, Chong CK, Hong SJ, Cha SH, Nam HW. Seroprevalence of toxoplasmosis in the residents of Cheorwon-gun, Gangwon-do, Korea. Korean J Parasitol 2012; 50: 225-227.

43. Shen G, Wang X, Sun H, Gao Y. Seroprevalence of Toxoplasma gondii infection among HIV/AIDS patients in Eastern China. Korean J Parasitol 2016; 54: 93-96.

44. Foroutan-Rad M, Khademvatan S, Majidiani H, Aryamand S, Rahim F, Malehi AS. Seroprevalence of Toxoplasma gondii in the Iranian pregnant women: A systematic review and meta-analysis. Acta Trop 2016; 158: 160-169.

45. Wilking H, Thamm M, Stark K, Aebischer T, Seeber F. Prevalence, incidence estimations, and risk factors of Toxoplasma gondii infection in Germany: a representative, cross-sectional, serological study. Sci Rep 2016; 6: 22551. 
